\title{
Utilization and Requirement of Egg Protein in Japanese Women
}

\author{
Kayoko KANEKO and Goro KoIKE ${ }^{1}$ \\ Kagawa Nutrition College, \\ Chiyoda 3-chome, Sakado, Saitama 350-02, Japan
}

(Received July 6, 1984)

\begin{abstract}
Summary Utilization and requirement of egg protein in Japanese women with two levels of energy intake were estimated. In experiment 1 , fifteen female students were given semi-purified diet containing whole egg as the sole nitrogen source for 12 days. Nitrogen intakes were 50 for five, 75 for two and $100 \mathrm{mg} \mathrm{N} / \mathrm{kg}$ for eight subjects. Habitual energy intake was determined individually by detailed inquiry about the foods consumed before the experiment was started. Mean energy intake was $33 \mathrm{kcal} / \mathrm{kg}$. In experiment 2, eighteen other subjects were given the same diet containing four intake levels of egg protein $(30,50,75,100 \mathrm{mg} \mathrm{N} / \mathrm{kg}$ ) with an energy intake of about $100 \mathrm{kcal} /$ day added to that calculated by the food intake inquiry. The mean energy intake was $37 \mathrm{kcal} / \mathrm{kg}$. The total nitrogen contents of the experimental diet, urine and feces were analyzed and the nitrogen balance was estimated from these figures. Significant rectilinear relations were found between nitrogen intake $(X, \mathrm{mg} \mathrm{N} / \mathrm{kg})$ and balance $(Y, \mathrm{mg} \mathrm{N} / \mathrm{kg}$ ). The regression equations were;
\end{abstract}

Experiment 1: $\quad Y=0.256 X-34.4(n=15, r=0.742)$

Experiment 2: $\quad Y=0.326 X-29.7(n=18, r=0.645)$

The maintenance intakes of whole egg protein for apparent nitrogen equilibrium were calculated to be 134 and $91 \mathrm{mg} \mathrm{N} / \mathrm{kg}$ with energy intakes of 33 and $37 \mathrm{kcal} / \mathrm{kg}$, respectively. Net protein utilization (NPU) and digestibility of egg protein were calculated using the obligatory $\mathrm{N}$ losses previously determined in Japanese women. The NPUs at the maintenance level of egg protein with energy intakes of 33 and $37 \mathrm{kcal} / \mathrm{kg}$ were estimated as 31 and 47 , respectively. The mean digestibility of egg protein was $96 \%$.

Key Words protein utilization, protein requirement, egg protein, women, energy intake

The present protein allowance suggested by the FAO/WHO(1) and the Committee on Nutrition (Japan)(2) is based on the amount of dietary protein needed to maintain the nitrogen $(\mathrm{N})$ balance in healthy male adults in laboratory

1 金子佳代子, 小池五郎 
tests. The dependence of the $\mathrm{N}$ balance on intakes of protein and energy is well known (3-6). Inoue et al. (3) and Kishi et al. (4) studied the effect of energy intake on protein requirement quantitatively. According to them, the nitrogen requirement of egg protein with maintenance energy intake was $90 \mathrm{mg} \mathrm{N} / \mathrm{kg}$ and the net protein utilization (NPU) of egg protein at nitrogen equilibrium was 55. Based on these data and obligatory $\mathrm{N}$ losses measured in Japanese male subjects, the protein requirement for Japanese adults was estimated (2). However, few reports have been made on obligatory $\mathrm{N}$ losses or protein requirement in female subjects. Thus the Committee have been compelled to take the same protein requirement figure for both sexes.

A previous study (7) in our laboratory on obligatory urinary and fecal $\mathrm{N}$ losses of Japanese female subjects showed that urinary loss was similar but fecal loss was lower compared with those of male subjects. In this work we estimated utilization and requirement of egg protein in Japanese female subjects at two levels of energy intake.

\section{EXPERIMENTAL}

Thirty-three female Japanese students aged 18 to 22 years participated in this study. During the experiments they lived in a metabolic unit and continued their usual activities. Table 1 summarized the characteristics of these subjects.

Subjects were given standard diet for 5 days before the experiments began. Standard diet was prepared from conventional foodstuffs containing about $60 \mathrm{~g}$ of protein per day and from the knowledge of approximate energy which was determined individually by detailed inquiry into foods consumed before the experiment. The mean of the energy intake was less than the allowance level for Japanese women, but the subjects maintained a constant weight during the period on standard diet. Thus, the energy intake level was regarded as sufficient to meet its expenditure. After the standard period, the subjects were given a semi-purified experimental diet.

\section{Experiment 1}

Fifteen subjects were given semi-purified experimental diet containing whole egg as sole nitrogen source for 12 days. The nitrogen intakes were $50 \mathrm{mg} \mathrm{N} / \mathrm{kg}$ for five subjects, $75 \mathrm{mg} \mathrm{N} / \mathrm{kg}$ for two and $100 \mathrm{mg} / \mathrm{kg}$ for eight. The energy intake was the same as that in the preceding standard period. The composition of the experimental diet is given in Table 2. Energy was supplied mainly from cornstarch, sucrose and shortening. Dietary fat supplied about $25 \%$ of the total energy intake.

The mean urinary nitrogen excretions in the last 4 days of the experimental period were used to estimate nitrogen balance. Apparent nitrogen balances were calculated from the nitrogen intake and fecal and urinary excretions. 
Table 1. Characteristics of subjects.

\begin{tabular}{|c|c|c|c|c|c|}
\hline No. & $\begin{array}{l}\text { Age } \\
(\mathrm{yr})\end{array}$ & $\begin{array}{l}\text { Height } \\
(\mathrm{cm})\end{array}$ & $\begin{array}{l}\text { Weight }^{\mathrm{a}} \\
\quad(\mathrm{kg})\end{array}$ & $\begin{array}{c}\mathrm{LBM}^{\mathrm{b}} \\
(\mathrm{kg})\end{array}$ & $\begin{array}{c}\text { BMR } \\
(\mathrm{kcal} / \mathrm{kg})\end{array}$ \\
\hline \multicolumn{6}{|c|}{ Experiment 1} \\
\hline 101 & 19 & 166 & 63.3 & 46.0 & 19.4 \\
\hline 102 & 19 & 160 & 55.4 & 44.2 & 22.0 \\
\hline 103 & 20 & 160 & 58.1 & 40.4 & 23.7 \\
\hline 104 & 20 & 157 & 57.4 & 40.3 & 23.6 \\
\hline 105 & 19 & 164 & 50.9 & 42.1 & 21.9 \\
\hline 106 & 18 & 151 & 56.7 & 42.4 & 22.0 \\
\hline 107 & 19 & 158 & 55.6 & 39.8 & 23.0 \\
\hline 108 & 22 & 156 & 54.1 & 40.3 & 21.1 \\
\hline 109 & 22 & 157 & 51.2 & 42.7 & 22.5 \\
\hline 110 & 22 & 158 & 57.4 & 42.4 & 18.8 \\
\hline 111 & 21 & 156 & 46.1 & 35.5 & 26.2 \\
\hline 112 & 20 & 152 & 49.2 & 35.0 & 24.0 \\
\hline 113 & 19 & 164 & 52.2 & 40.6 & 25.7 \\
\hline 114 & 21 & 150 & 43.4 & 33.9 & 23.4 \\
\hline 115 & 21 & 156 & 51.4 & 41.0 & 20.6 \\
\hline Mean & 20.1 & 157.7 & 53.5 & 40.4 & 22.5 \\
\hline SD & 1.3 & 4.7 & 5.1 & 3.4 & 2.1 \\
\hline \multicolumn{6}{|c|}{ Experiment 2} \\
\hline 201 & 19 & 160 & 58.4 & 40.6 & 21.0 \\
\hline 202 & 21 & 152 & 52.2 & 35.0 & 22.6 \\
\hline 203 & 21 & 160 & 59.0 & 39.4 & 17.2 \\
\hline 204 & 20 & 149 & 58.8 & 46.8 & 18.7 \\
\hline 205 & 21 & 160 & 50.1 & 40.5 & 24.9 \\
\hline 206 & 21 & 156 & 46.3 & 34.8 & 20.8 \\
\hline 207 & 21 & 159 & 51.9 & 33.7 & 20.7 \\
\hline 208 & 21 & 162 & 56.1 & 39.2 & 19.7 \\
\hline 209 & 21 & 157 & 48.2 & 39.9 & 19.8 \\
\hline 210 & 20 & 158 & $\dot{4} 9.2$ & 37.4 & 21.6 \\
\hline 211 & 20 & 148 & 52.3 & 38.4 & 22.9 \\
\hline 212 & 19 & 160 & 53.9 & 36.1 & 19.8 \\
\hline 213 & 19 & 155 & 55.1 & 38.9 & 20.7 \\
\hline 214 & 18 & 148 & 49.3 & 34.9 & 20.9 \\
\hline 215 & 19 & 158 & 51.2 & 35.7 & 22.6 \\
\hline 216 & 19 & 160 & 57.0 & 40.6 & 21.5 \\
\hline 217 & 20 & 156 & 47.2 & 35.8 & 19.3 \\
\hline 218 & 18 & 160 & 61.2 & 42.7 & 22.7 \\
\hline Mean & 20.0 & 156.6 & 53.1 & 38.4 & 21.0 \\
\hline SD & 1.1 & 4.5 & 4.5 & 3.3 & 1.8 \\
\hline
\end{tabular}

${ }^{\mathrm{a}}$ Mean of 5 days given the standard diet. ${ }^{\mathrm{b}}$ Calculated from hydrometrically measured body density. 
Table 2. Composition of semi-purified experimental diet. ${ }^{\mathrm{a}}$

\begin{tabular}{ll}
\hline \multicolumn{1}{c}{ Ingredient } & Intake $(\mathrm{g} /$ day $)$ \\
\hline Whole egg & 250 \\
Cornstarch & 180 \\
Sugar & 140 \\
Shortening & 31 \\
Agar & 5 \\
Sodium chloride & 3 \\
Mineral mixture & 4 \\
Vitamin mixture $^{\mathrm{b}}$ & 2 tablets \\
\hline
\end{tabular}

${ }^{\mathrm{a}}$ Intake is given for subject receiving $1,800 \mathrm{kcal}$ and $100 \mathrm{mg} \mathrm{N} / \mathrm{kg}$ diet. Besides this diet, the subjects consumed black tea, green tea and lemon juice. ${ }^{b}$ For details, see Reference (7).

\section{Experiment 2}

Eighteen subjects were given the same, semi-purified experimental diet containing four intake levels of whole egg $(30,50,75,100 \mathrm{mg} \mathrm{N} / \mathrm{kg})$ with an energy intake of about $100 \mathrm{kcal} / \mathrm{day}$ added to that of the standard period. Constituents of the diet were the same as those of experiment 1 .

Throughout the experiment, subjects were weighed daily before breakfast after voiding urine. Urine was collected every $24 \mathrm{~h}$ and feces in the experimental period were pooled. The total nitrogen contents of diet, urine and feces were analyzed by the semimicro-Kjeldahl method. Urinary creatinine was determined by the method of Folin (8). Basal metabolism was measured on a selected day during the experimental period. Lean body mass was calculated from the body density measured hydrometrically by using the equation of Brožek (9).

\section{RESULTS}

Energy intake, changes in body weight, urinary creatinine excretion, nitrogen intake and excretion, and nitrogen balance in each subject are given in Table 3 . Mean energy intake in experiments 1 and 2 were $33.1 \pm 3.5$ and $37.3 \pm 3.5 \mathrm{kcal} / \mathrm{kg}$, respectively. When the subjects were given the standard diet with approximate maintenance energy intake determined by inquiry into food consumption and with a protein intake of $60 \mathrm{~g} /$ day, their body weights did not change significantly. Mean body weight throughout the 5-day period was regarded as the initial weight of each subject. On changing to semi-purified experimental diet, the body weights of all subjects in experiment 1 decreased, while those of the subjects in experiment 2 were maintained or decreased slightly. Urinary creatinine excretion was constant throughout the experimental period in all subjects.

In both experiments, urinary nitrogen excretion decreased rapidly to fairly 


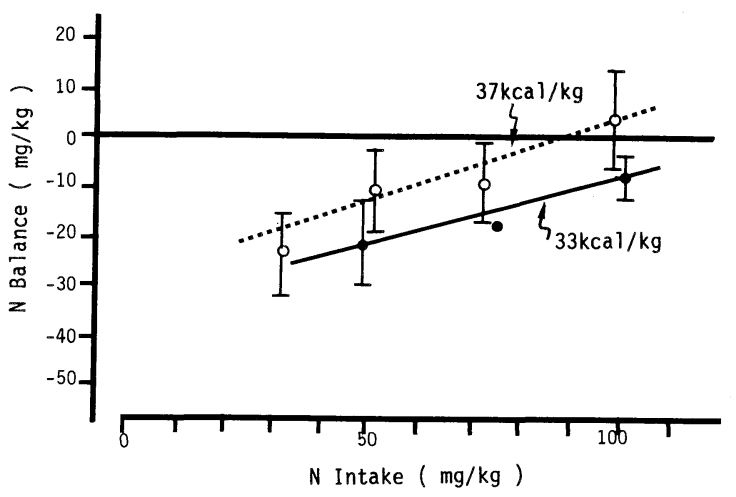

Fig. 1. Relation between nitrogen intake and nitrogen balance in female subjects given egg protein with energy intakes of $33 \mathrm{kcal} / \mathrm{kg}(\bullet)$ and $37 \mathrm{kcal} / \mathrm{kg}(\bigcirc)$.

steady levels within a week of changing to the experimental diet from the siandard diet. Nitrogen balance improved with an increase in nitrogen intake in both experiments 1 and 2. Significant rectilinear relations were found between nitrogen intake $(X, \mathrm{mg} \mathrm{N} / \mathrm{kg})$ and balance $(Y, \mathrm{mg} \mathrm{N} / \mathrm{kg})$ as shown in Fig. 1. The regression equation are as follows:

Experiment 1: $Y=0.256 X-34.4(n=15, r=0.742)$

Experiment 2: $Y=0.326 X-29.7(n=18, r=0.645)$

From the above equations, the maintenance intakes of whole egg protein for apparent nitrogen equilibrium were calculated to be 134 and $91 \mathrm{mg} \mathrm{N} / \mathrm{kg}$ with energy intakes of 33 and $37 \mathrm{kcal} / \mathrm{kg}$, respectively.

NPU and digestibility of egg protein were calculated using the obligatory urinary and fecal $\mathrm{N}$ losses (32.3 and $10.1 \mathrm{mg} \mathrm{N} / \mathrm{kg}$, respectively) determined in Japanese women (7); these are summarized in Table 4. Mean values of digestibility were 96.4 and $95.4 \%$ in experiments 1 and 2, respectively. The NPUs of egg protein obtained at intake levels of 50,75 and $100 \mathrm{mg} \mathrm{N} / \mathrm{kg}$ were 42,30 , and 33 with an energy intake of $33 \mathrm{kcal} / \mathrm{kg}$, and at $30,50,75,100 \mathrm{mg} \mathrm{N} / \mathrm{kg}$ with an energy intake of $37 \mathrm{kcal} / \mathrm{kg}$ were $59,62,42$ and 46 , respectively. The NPU values at the maintenance level of egg protein with an energy intake of 33 and $37 \mathrm{kcal} / \mathrm{kg}$ were estimated as 31 and 47 , respectively.

\section{DISCUSSION}

Inoue et al. (3) and Kishi et al. (4) studied the effect of energy intake on protein requirement quantitatively. They found that the nitrogen requirement of egg protein decreased with an increase in energy intake; that is, it was $124 \mathrm{mg} \mathrm{N} / \mathrm{kg}$ at $40 \mathrm{kcal}, 90 \mathrm{mg} \mathrm{N} / \mathrm{kg}$ at $45 \mathrm{kcal} / \mathrm{kg}, 82 \mathrm{mg} \mathrm{N} / \mathrm{kg}$ at $48 \mathrm{kcal} / \mathrm{kg}$, and $67 \mathrm{mg} \mathrm{N} / \mathrm{kg}$ at $57 \mathrm{kcal} / \mathrm{kg}$ of energy intake in their male subjects. We investigated the nitrogen requirement of egg protein in women at two levels of energy intake, 33 and 


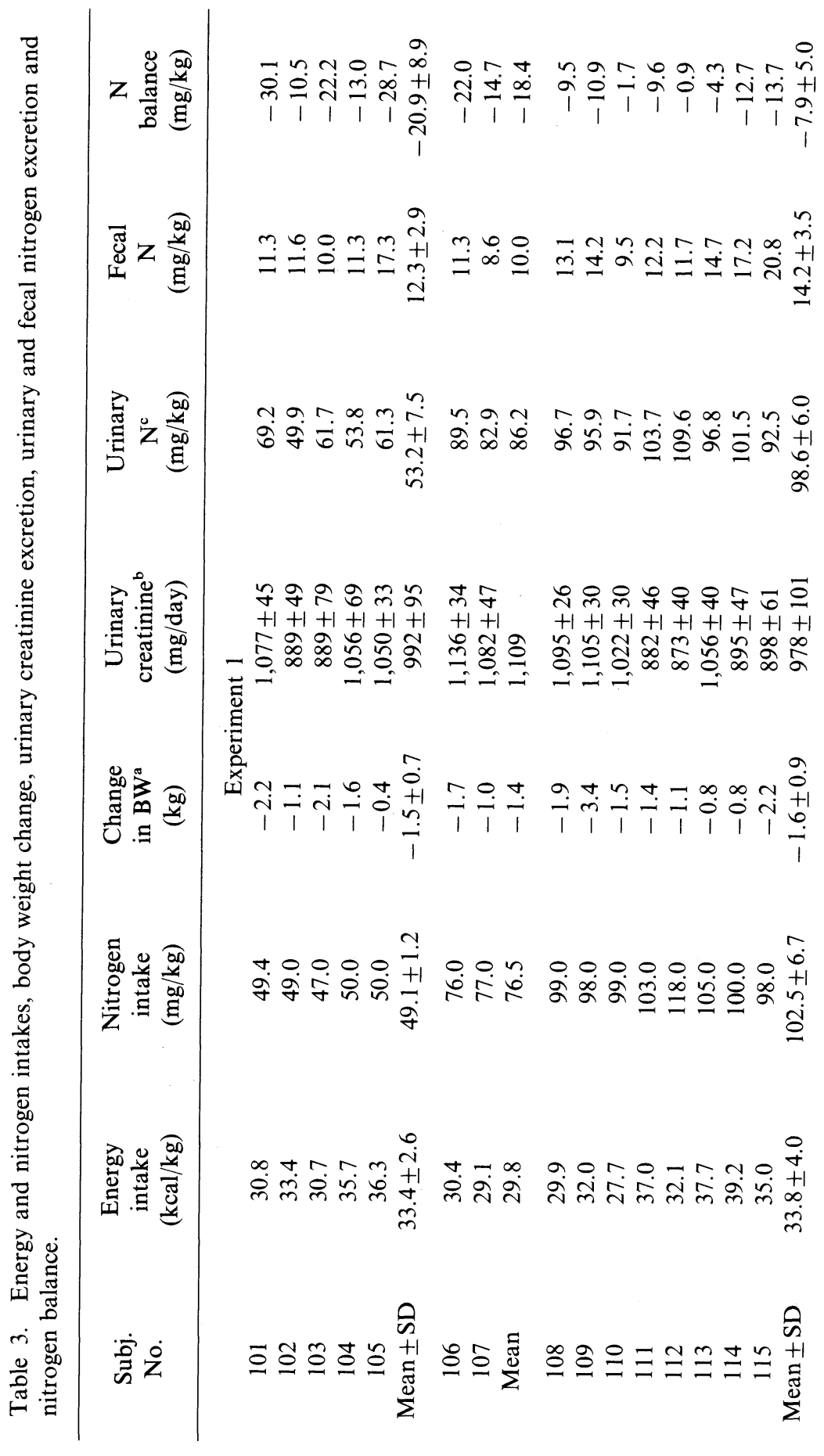




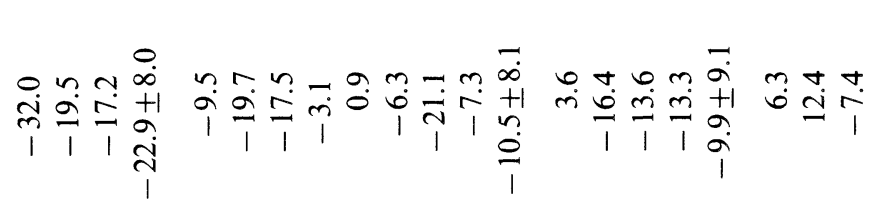

$\sum_{0}^{+}$

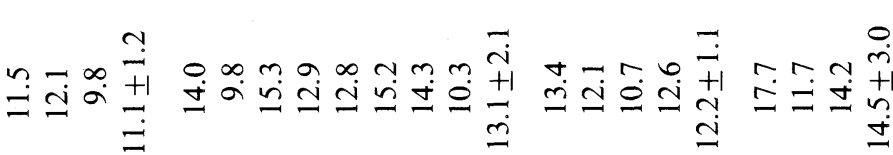

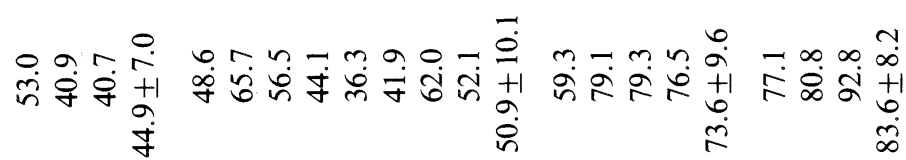

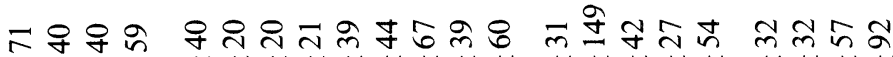
$+1+1+1+1+1+1+1+1+1+1+1+1+1+1+1+1+1+1+1+1+1+1$ N

节

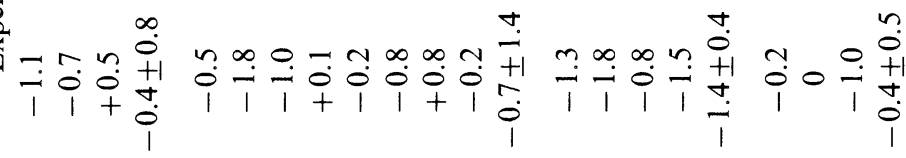

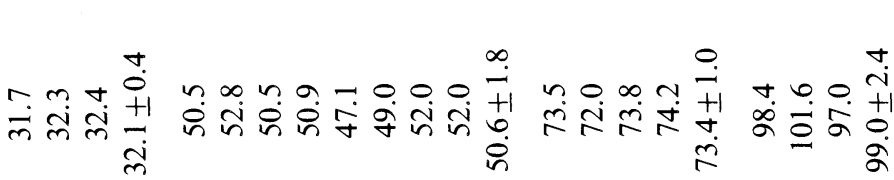

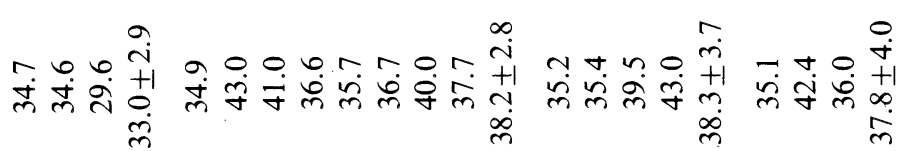

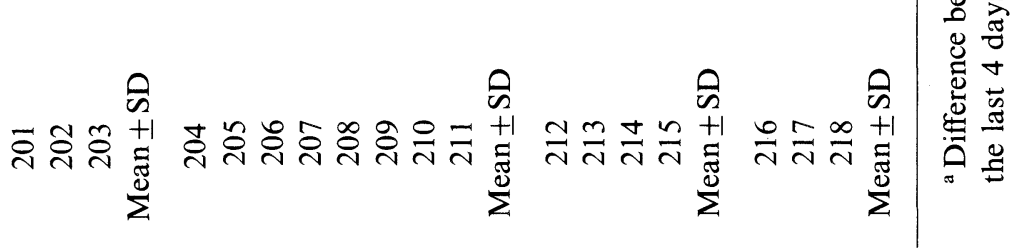
Vol. 31, No. 1, 1985 
Table 4. Net protein utilization (NPU) and digestibility of egg protein.

\begin{tabular}{ccccc}
\hline & $\begin{array}{c}\text { N intake } \\
(\mathrm{mg} / \mathrm{kg})\end{array}$ & No. & NPU $^{\mathrm{a}}$ & $\begin{array}{c}\text { Digestibility } \\
(\%)\end{array}$ \\
\hline \multirow{3}{*}{ Experiment 1} & 50 & 5 & 42 & 96 \\
& 75 & 2 & 30 & 100 \\
& 100 & 8 & 33 & 96 \\
\hline Experiment 2 & 30 & 3 & 59 & 97 \\
& 50 & 8 & 62 & 94 \\
& 75 & 4 & 42 & 97 \\
\hline
\end{tabular}

${ }^{a}$ Calculated using values of 32.3 and $10.1 \mathrm{mg} / \mathrm{kg}$ for endogenous urinary and fecal nitrogen losses, respectively. ${ }^{\mathrm{b}}$ Calculated using the value of $10.1 \mathrm{mg} / \mathrm{kg}$ for obligatory fecal $\mathrm{N}$ loss.

$37 \mathrm{kcal} / \mathrm{kg}$. And we found that less egg protein nitrogen was required and that higher $Y$ intercept and NPU figures were obtained when more energy was supplied. Comparing our results in females to those in male subjects, the nitrogen requirement of egg protein for females was almost same as for males at an energy intake aimed at weight maintenance during the experimental period, i.e., $37 \mathrm{kcal} / \mathrm{kg}$ for women and $45 \mathrm{kcal} / \mathrm{kg}$ for men. Furthermore, we calculated the maintenance intake of egg protein per unit basal energy expenditure (basal metabolism, BM) or per unit lean body mass (LBM) from the regression equations obtained from nitrogen intake and balance per these units, respectively. The respective values obtained were $5.93 \mathrm{mg} \mathrm{N} / \mathrm{kcal} \mathrm{BM}$ and $177 \mathrm{mg} \mathrm{N} / \mathrm{kg} \mathrm{LBM}$ in experiment 1 and $4.20 \mathrm{mg} \mathrm{N} / \mathrm{kcal} \mathrm{BM}$ and $132 \mathrm{mg} \mathrm{N} / \mathrm{kg}$ LBM in experiment 2 . To compare the two figures of protein requirement in men and women in detail, further discussion, for example as already referred to above, should be necessary.

In many studies on the minimum need for dietary protein in humans, subjects were provided a higher energy intake than the recommended level in order to increase or maintain body weight during the experimental period. Consequently, a relatively low figure for minimum $\mathrm{N}$ was obtained. The requirement of egg protein has been reported to be $4.8 \mathrm{~g} \mathrm{~N} /$ day ( $68 \mathrm{mg} \mathrm{N} / \mathrm{kg}$ for $70.1 \mathrm{~kg}$ body weight) (10) or 60-94 mg N/kg (11) in Caucasian male subjects. Recently, however, Calloway (6) reported a figure of $89 \mathrm{mg} \mathrm{N} / \mathrm{kg}$ with an energy intake of $41.2 \mathrm{kcal} / \mathrm{kg}$ to be required for body weight maintenance in her male subjects. The energy intakes was $70 \%$ higher than the measured basal expenditure. Huang and Lin (12) reported that $98 \mathrm{mg} \mathrm{N} / \mathrm{kg}$ of egg protein was required with an energy intake of $42 \mathrm{kcal} / \mathrm{kg}$ in Chinese male subjects. In these recent studies the investigators determined the optimal energy intake of their subjects. They measured basal expenditure or inquired into the dietary intake and physical activity of their subjects. We investigated the maintenance energy intake for individual subjects by inquiry into 
their food consumption prior to the start of the experiment, our subjects being fellow students in our college and trained to give accurate information on food consumption. The mean of their energy intakes was $34.4 \pm 3.6 \mathrm{kcal} / \mathrm{kg}$ body weight or $1.60 \pm 0.18 \mathrm{kcal} / \mathrm{kcal} \mathrm{BM}(n=33)$. With the energy intake provided, body weight was maintained at a constant levels in the standard period but decreased on changing to semi-purified experimental diet in experiment 1. Activities of the subjects did not change throughout the standard and experimental period. The duration of the standard period might be too short or there might be other reasons contributing to the reduction in weight, for example, loss of body water as a result of a sudden decrease in sodium intake from about $12 \mathrm{~g} /$ day in the standard diet period to $3 \mathrm{~g} /$ day in the semi-purified experimental diet period. This should be further investigated in the future.

In addition, urinary nitrogen excretion (UNE) in female subjects has been reported to vary with the menstrual cycle with a constant intake of energy and protein (13). The menstrual cycle was not taken into account in this study. Larger coefficients of variation of UNE in our subjects than for male subjects (4) might be partly caused by the menstrual cycle, and this variation of UNE with the menstrual cycle should be carefully considered when determining the requirement and utilization of protein in female subjects in the future.

We are grateful to Prof. Goro Inoue, Nakamura Gakuen College, for valuable suggestions.

\section{REFERENCES}

1) Report of a Joint FAO/WHO Ad Hoc Expert Committee (1973): Energy and Protein Requirements, Wld. Hlth./Org. Techn. Rep. Ser. No. 522.

2) Committee on Nutrition (Japan) (1979): Dietary protein allowances, in Recommended Dietary Allowances for Japanese, Ministry of Health and Welfare, Tokyo.

3) Inoue, G., Fujita, Y., and Niiyama, Y. (1973): Studies on protein requirements of young men fed egg protein and rice protein with excess and maintenance energy intakes. J. Nutr., 103, 1673-1687.

4) Kishi, K., Miyatani, S., and Inoue, G. (1978): Requirement and utilization of egg protein by Japanese young men with marginal intakes of energy. J. Nutr., 108, 658-669.

5) Garza, C., Scrimshaw, N. S., and Young, V. R. (1976): Human protein requirements: The effect of variation in energy intake within the maintenance range. Am. J. Clin. Nutr., 29, 280-287.

6) Calloway, D. H. (1975): Nitrogen balance of men with marginal intakes of protein and energy. J. Nutr., 105, 914-923.

7) Kaneko, K., and Koike, G. (1983): Obligatory N loss and utilization of egg and rice mixed protein in young Japanese women. J. Nutr. Sci. Vitaminol., 29, 455-466.

8) Koishi, H. (1962): A critical examination on the Folin's method for determination of creatinine concentration in the urine. Osaka City Med. J., 8, 1-15.

9) Brožek, J., Grand, F., Anderson, J. T., and Keys, A. (1963): Densitometric analysis of body composition: Revision of some quantitative assumptions. Ann. N. Y. Acad. Sci., 110, 113-140. 
10) Calloway, D. H., and Margen, S. (1971): Variation in endogenous nitrogen excretion and dietary nitrogen utilization as determinants of human protein requirement. $J$. Nutr., 101, 205-216.

11) Young, V. R., Taylor, Y.S.M., Rand, W. M., and Scrimshaw, N. S. (1973): Protein requirements of man: Efficiency of egg protein utilization at maintenance and submaintenance levels in young men. J. Nutr., 103, 1164-1174.

12) Huang, P.-C., and Lin, C. P. (1982): Protein requirements of young Chinese male adults on ordinary Chinese mixed diet and egg diet at ordinary levels of energy intake. $J$. Nutr., 112, 897-907.

13) Calloway, D. H., and Kurzer, M. S. (1982): Menstrual cycle and protein requirements of women. J. Nutr., 112, 356-366. 